\title{
Pengaruh Gaya Kognitif Terhadap Kemampuan Pemecahan Masalah Matematis Siswa
}

\author{
Halida Eka Nurmutia \\ Universitas Islam Negeri Walisongo Semarang \\ halidaeka10@gmail.com
}

\begin{abstract}
The objective of this study is to determine effect of cognitive style on students' mathematical problem solving ability. This study used survey method with a quantitative approach. One class consisting of 32 students was selected by purposive sampling for the study sample. A total of 17 students have a field dependent (FD) cognitive style, while 15 other students have a field independent (FI) cognitive style. GEFT and mathematical problem solving ability test instruments were used to collect research data. Data were analyzed using Pearson Product Moment correlation test and simple regression test. The research results found that there is a strong positive relationship between cogntive style and students' mathematical problem solving ability, indicated by correlation coefficient $r=0,636$. In addition, cognitive style has an effect on students' mathematical problem solving ability of $40,5 \%$ through a linear relationship $\hat{Y}=3,703+0,512 X$.
\end{abstract}

Keywords: cognitive style, field dependent, field independent, mathematical problem solving ability

\begin{abstract}
Abstrak. Penelitian ini bertujuan untuk mengetahui pengaruh gaya kognitif terhadap kemampuan pemecahan masalah matematis siswa. Metode penelitian yang digunakan adalah metode survei dengan pendekatan kuantitatif. Satu kelas yang terdiri atas 32 siswa dipilih secara purposive sampling untuk sampel penelitian. Sebanyak 17 siswa memiliki gaya kognitif field dependent (FD), sedangkan 15 siswa lainnya memiliki gaya kognitif field independent (FI). Instrumen yang digunakan untuk mengumpulkan data, yaitu GEFT dan tes kemampuan pemecahan masalah matematis. Analisis data hasil penelitian menggunakan uji korelasi Product Moment Pearson dan uji regresi sederhana. Adapun hasil penelitian yang diperoleh adalah terdapat hubungan positif yang kuat antara gaya kognitif dan kemampuan pemecahan masalah matematis siswa, ditunjukkan dengan nilai koefisien korelasi $r=0,636$. Selain itu, gaya kognitif berpengaruh terhadap kemampuan pemecahan masalah matematis siswa sebesar $40,5 \%$ melalui hubungan linear $\hat{Y}=3,703+0,512 X$.
\end{abstract}

Kata kunci: gaya kognitif, field dependent; field independent, kemampuan pemecahan masalah matematis 


\section{PENDAHULUAN}

Implementasi kurikulum 2013 dalam sistem pendidikan Indonesia saat ini berfokus pada pengembangan keterampilan berpikir tingkat tinggi agar siswa mempunyai keterampilan dan kemampuan sebagai modal untuk menghadapi tantangan di era persaingan global. Salah satu kemampuan yang melibatkan proses berpikir tingkat tinggi dan esensial untuk dimiliki siswa pada abad 21 ini adalah kemampuan pemecahan masalah (Elita, Habibi, Putra \& Ulandari, 2019). Branca dalam Hendriana dan Soemarmo (2014) menyatakan bahwa proses pemecahan masalah matematis adalah jantungnya matematika. Kemampuan pemecahan masalah matematis merupakan kemampuan dasar dalam pembelajaran matematika sehingga memungkinkan siswa untuk mengembangkan pemikiran analitis, menjadi kritis dan kreatif, serta meningkatkan kemampuan matematika lainnya. Mempelajari pemecahan masalah matematis berarti belajar untuk berpikir, menalar, dan menerapkan pengetahuan yang dimiliki (Hendriana, Johanto \& Soemarmo, 2018).

Beberapa penelitian mengenai kemampuan pemecahan masalah telah banyak dilakukan dan menunjukkan bahwa kemampuan pemecahan masalah matematis siswa, baik di tingkat pendidikan menengah maupun pendidikan tinggi masih rendah (Shodikin, 2015). Rendahnya kemampuan pemecahan masalah matematis yang dialami siswa disebabkan oleh beberapa faktor, salah satunya karena siswa tidak terbiasa berlatih dalam pemecahan masalah. Siswa terbiasa menghafal definisi, teorema, dan rumus-rumus matematika (Susanto, 2015). Di sisi lain, karakter siswa dalam proses kognitif juga kurang mendapatkan perhatian pada saat proses pembelajaran.

Menurut Jena (2014), cara siswa belajar dan menangani masalah sangat tergantung pada hubungan antara kepribadian dan kognisi yang disebut dengan gaya kognitif. Gaya kognitif adalah proses psikologis individu untuk memahami dan bereaksi dengan lingkungannya. Hal ini berkaitan dengan cara berpikir seseorang, pemecahan masalah, dan belajar. Gaya kognitif disebut sebagai gaya, bukan sebagai kemampuan karena merujuk pada cara seseorang memproses informasi dan memecahkan masalah, bukan merujuk pada bagaimana proses penyelesaian yang terbaik (Saracho, 1997). Stenberg dan Zang (dalam Arnup, Murrihy, Roodenburg \& McLean, 2013) juga menyatakan bahwa gaya kognitif merupakan prediktor kinerja akademik yang lebih baik daripada Intelligence Quotient.

Salah satu dimensi gaya kognitif yang luas dieksplorasi dan telah memiliki aplikasi luas untuk masalah pendidikan adalah dimensi field dependent (FD) dan field independent (FI) (Lu \& Lin, 2018). Individu dengan gaya kognitif FD dan FI memiliki perbedaan dalam metode memproses informasi. Individu FD cenderung global dalam menganalisis situasi belajar. Mereka memiliki kesulitan dalam memecahkan informasi ke dalam bagian yang tertutup, dan tidak menganggap item berbeda dari konteksnya. Siswa FD biasanya lebih suka pembelajaran langsung dan cenderung menjadi pembelajar insidental dalam konteks sosial, serta kesulitan menggunakan intuisi. Di sisi lain, individu FI cenderung lebih baik dalam kegiatan analitis. Mereka bisa memecahkan masalah yang kompleks, mengingat informasi, memandang item memiliki ciri yang berbeda dari konteksnya, umumnya dapat mengkodekan informasi dengan cepat dan akurat, dan dapat mengerjakan dengan baik tes yang telah distandarkan (Richardson \& Turner dalam Onyekuru, 2015).

Sebagai karakteristik perilaku, karakteristik individu yang memiliki gaya kognitif yang sama belum tentu memiliki kemampuan yang sama (Mall-Amiri \& Arabgol, 2015). Tidak dapat dikatakan bahwa seseorang yang mempunyai skor lebih tinggi pada tes gaya kognitif lebih baik dalam setiap keadaan dibanding seseorang yang mempunyai skor yang lebih rendah pada tes gaya 
kognitif. Penelitian terdahulu menunjukkan bahwa terdapat hubungan positif antara gaya kognitif Field Dependent-Independent dan prestasi akademik siswa (Mefoh \& Ezeh, 2016). Berdasarkan uraian di atas, peneliti memandang perlu dilakukan penelitian untuk mengetahui pengaruh gaya kognitif terhadap kemampuan pemecahan masalah matematis siswa.

\section{METODE}

Penelitian ini merupakan jenis penelitian kuantitatif dengan metode survei. Menurut Indrawan \& Poppy (2016), metode survei bertujuan untuk melihat keadaan yang menjadi objek penelitian apa adanya, dengan melihat data dan informasi yang ada dalam sampel, tanpa memberikan perlakuan khusus. Populasi terjangkau dalam penelitian ini adalah siswa SMP 2 Rembang kelas VII. Pengambilan sampel penelitian menggunakan teknik purposive sampling. Peneliti memilih satu kelas heterogen yang terdiri atas 32 siswa.

Instrumen yang digunakan dalam penelitian ini ada dua macam, yaitu Group Embedded Figures Test (GEFT) dan tes kemampuan pemecahan masalah matematis. GEFT merupakan instrument tes terstandar yang dikembangkan oleh Witkin et al. pada tahun 1971. Koefisien reliabilitas GEFT untuk keseluruhan tes adalah 0,86 sehingga instrumen ini sudah layak untuk digunakan langsung dalam penelitian. GEFT terdiri atas tiga bagian, yaitu bagian I terdiri dari 7 soal, sedangkan bagian II dan bagian III masing-masing terdiri dari 9 soal. Untuk setiap jawaban benar diberikan skor 1 dan jawaban salah diberi skor 0 (Khatib dan Hosseinpur, 2011). Kriteria gaya kognitif siswa dapat dilihat pada Tabel 1 .

Tabel 1. Kriteria Gaya Kognitif

\begin{tabular}{lc}
\hline Jenis Gaya Kognitif & Skor \\
\hline Field Dependent $(F D)$ & $0 \leq x \leq 11$ \\
Field Independent $(F I)$ & $12 \leq x \leq 18$ \\
\hline
\end{tabular}

Instrumen tes kemampuan pemecahan masalah matematis (TKPMM) berupa tes uraian sebanyak empat soal yang valid dan signifikan. Koefisien reliabilitas tes ini sebesar 0,651 sehingga termasuk dalam kategori reliabilitas tinggi. Adapun pedoman penilaian tes kemampuan pemecahan masalah matematis siswa dalam penelitian ini mengadopsi dari Charles (1994), yaitu penskoran holistik, dimana interval skor pada setiap butir soal adalah $0-4$. Data yang telah dikumpulkan diolah menggunakan bantuan software SPSS 25.0. Analisis statistik untuk menganalisis data hasil penelitian ini adalah statistik deskriptif dan statistik inferensial. Statistik deskriptif digunakan untuk mendeskripsikan data yang meliputi persentase, nilai maksimum, nilai minimum, rata-rata, dan standar deviasi. Uji statistik inferensial yang digunakan adalah uji korelasi Pearson Product Moment dan uji regresi sederhana.

\section{HASIL DAN PEMBAHASAN}

Gaya kognitif subjek penelitian diidentifikasi menggunakan instrumen GEFT. Data gaya kognitif field dependent dan field independent yang dimiliki siswa disajikan pada Tabel 2.

Tabel 2. Data Gaya Kognitif Siswa

\begin{tabular}{lc}
\hline Jenis Gaya Kognitif & Skor \\
\hline Field Dependent $(F D)$ & 17 \\
Field Independent $(F I)$ & 15 \\
\hline
\end{tabular}


Dari tabel tersebut dapat dilihat bahwa sebanyak 17 (53,125\%) siswa memiliki gaya kognitif FD dan $15(46,875 \%)$ siswa memiliki gaya kognitif FI.

Data kuantitatif hasil penelitian diperoleh dengan cara memeriksa hasil GEFT dan TKPMM siswa, kemudian diolah sesuai dengan rubrik penskoran yang telah ditetapkan. Analisis deskriptif data hasil penelitian disajikan secara lengkap pada Tabel 3.

Tabel 3. Analisis Deskriptif Data Penelitian

\begin{tabular}{cc|c|c|c|c}
\hline & N & Minimum & Maksimum & Mean & Std. Deviation \\
\hline Gaya Kognitif & 32 & 1 & 17 & 10,25 & 4,421 \\
\hline TKPMM & 32 & 3,0 & 15,0 & 8,953 & 3,5591 \\
\hline Valid N (listwise) & 32 & & & & \\
\hline
\end{tabular}

Analisis inferensial pada penelitian ini meliputi uji korelasi Pearson Product Moment dan regresi sederhana untuk mengetahui signifikansi hubungan, serta pengaruh gaya kognitif terhadap kemampuan pemecahan masalah matematis siswa. Sebelum uji korelasi dan regresi, dilakukan analisis uji normalitas dan homogenitas data hasil TKPMM sebagai uji prasyarat.

Uji normalitas data skor TKPMM menggunakan uji Shapiro-Wilk, sedangkan uji homogentitas menggunakan uji Lavene's Test dengan taraf signifikansi $(\alpha)$ masing-masing sebesar 0,05. Kriteria pengujian yang digunakan, yaitu jika nilai sig. $($-value $)<\alpha(0,05)$, maka $\mathrm{H}_{0}$ ditolak dan untuk kondisi lain $\mathrm{H}_{0}$ diterima. Hasil uji normalitas menunjukkan nilai sig. $(0,112)>\alpha(0,05)$ sehingga dapat disimpulkan bahwa $\mathrm{H}_{0}$ diterima. Artinya, data berdistribusi normal. Untuk uji homogenitas diperoleh nilai sig. $(0,611)>\alpha(0,05)$ sehingga dapat disimpulkan bahwa $\mathrm{H}_{0}$ diterima. Artinya, variansi data skor hasil TKPMM homogen.

Uji korelasi dilakukan dengan menggunakan uji korelasi Pearson Product Moment dengan taraf signifikansi 0,05 . Kriteria pengujian yang digunakan, yaitu jika nilai sig. $(p$-value $)<\alpha(0,05)$, maka $\mathrm{H}_{0}$ ditolak dan untuk kondisi lain $\mathrm{H}_{0}$ diterima. Hasil rangkuman uji korelasi Pearson antara gaya kognitif dan kemampuan pemecahan masalah matematis siswa disajikan pada Tabel 4.

Tabel 4. Uji Korelasi Pearson

\begin{tabular}{ccc|c}
\hline & & Gaya Kognitif & KPMM \\
\hline \multirow{2}{*}{$\begin{array}{c}\text { Gaya } \\
\text { Kognitif }\end{array}$} & Pearson Correlation & 1 &, $636^{* * *}$ \\
\cline { 2 - 4 } & Sig. (2-tailed) &, 000 \\
\cline { 2 - 4 } & $\mathrm{N}$ & 32 & 32 \\
\cline { 2 - 4 } KPMM & Pearson Correlation &, $636^{* * *}$ & 1 \\
\cline { 2 - 4 } & Sig. (2-tailed) &, 000 & 32 \\
\hline
\end{tabular}

Berdasarkan hasil uji korelasi pada Tabel 4 diperoleh nilai sig. $(0,00)<\alpha(0,05)$ sehingga dapat disimpulkan bahwa $\mathrm{H}_{0}$ ditolak. Artinya, terdapat hubungan yang signifikan antara gaya kognitif dan kemampuan pemecahan masalah siswa. Nilai koefisien korelasi $(r)$ antara gaya kognitif dan KPMM sebesar 0,636. Menurut pedoman interpretasi terhadap koefisien korelasi, interval koefisien 0,60 - 0,799 termasuk dalam tingkat hubungan yang kuat (Sugiyono, 2010). Artinya, terdapat hubungan positif yang kuat antara gaya kognitif dan kemampuan pemecahan masalah matematis siswa.

Uji regresi sederhana digunakan untuk mengetahui pengaruh gaya kognitif terhadap kemampuan pemecahan masalah matematis siswa. Adapun hasil analisis regresi sederhana disajikan pada Tabel 5 . 


\begin{tabular}{|c|c|c|c|c|c|c|}
\hline \multicolumn{7}{|c|}{ Tabel 5. Uji Korelasi Pearson } \\
\hline & \multirow{2}{*}{ Model } & \multicolumn{2}{|c|}{ Unstandardized Coefficients } & \multirow{2}{*}{$\begin{array}{c}\begin{array}{c}\text { Standardized } \\
\text { Coefficients }\end{array} \\
\text { Beta }\end{array}$} & \multirow[t]{2}{*}{$\mathbf{t}$} & \multirow[t]{2}{*}{ Sig. } \\
\hline & & $\mathbf{B}$ & Std. Error & & & \\
\hline \multirow{2}{*}{1} & (Constant) & 3,703 & 1,263 & & 2,933 & 006 \\
\hline & GayaKognitif &, 512 &, 113 & 636 & 4,517 & 000 \\
\hline
\end{tabular}

a. Dependent Variable: KPMM

Berdasarkan Tabel 5 diperoleh konstanta $a=3,703$ dan arah regresi $b=0,512$ sehingga dapat dirumuskan persamaan regresi $\hat{Y}=3,703+0,512 X$. Selanjutnya, dilakukan uji linearitas terhadap persamaan regresi untuk mengetahui apakah gaya kognitif berpengaruh terhadap kemampuan pemecahan masalah matematis siswa.

Uji linearitas menggunakan taraf signifikansi 0,05 . Kriteria pengujian yang digunakan, yaitu jika nilai sig.(p-value $)<\alpha(0,05)$, maka $\mathrm{H}_{0}$ ditolak dan untuk kondisi lain $\mathrm{H}_{0}$ diterima. Hasil rangkuman uji linearitas disajikan pada Tabel 6.

Tabel 6. Uji Korelasi Pearson

\begin{tabular}{|c|c|c|c|c|c|c|}
\hline & Model & Sum of Squares & Df & Mean Square & $\mathbf{F}$ & Sig. \\
\hline \multirow{3}{*}{1} & Regression & 158,965 & 1 & 158,965 & 20,405 & ,000b \\
\hline & Residual & 233,715 & 30 & 7,790 & & \\
\hline & Total & 392,680 & 31 & & & \\
\hline
\end{tabular}

Pada Tabel 6 dapat dilihat bahwa nilai sig. $(0,00)<\alpha(0,05)$ sehingga dapat disimpulkan bahwa $\mathrm{H}_{0}$ ditolak. Jadi, persamaan linear atau gaya kognitif berpengaruh secara positif terhadap kemampuan pemecahan masalah matematis siswa. Besarnya pengaruh gaya kognitif dapat diketahui melalui nilai koefisien determinasi $\mathrm{R}^{2}$, yaitu sebesar 0,405 atau 40,5\%. Dengan kata lain, gaya kognitif mempengaruhi kemampuan pemecahan masalah matematis siswa sebesar $40,5 \%$, masih ada 59,5\% kemampuan pemecahan masalah matematis siswa dipengaruhi oleh variabel lain selain gaya kognitif, misalnya model pembelajaran, self efficacy, atau faktor-faktor lainnya.

Hasil analisis data penelitian menunjukkan bahwa terdapat hubungan positif yang kuat antara gaya kognitif dan kemampuan pemecahan masalah matematis siswa. Siswa yang mempunyai skor tinggi pada GEFT juga memperoleh skor tinggi pada TKPMM. Dengan demikian, dapat dikatakan bahwa siswa FI mempunyai kemampuan pemecahan masalah matematis lebih baik dibandingkan dengan siswa FD. Hal ini dapat pula dilihat dari rata-rata skor hasil tes kemampuan pemecahan masalah matematis siswa FI yang mendapatkan rata-rata skor 10,93 lebih tinggi dibandingkan dengan rata-rata skor siswa FD, yaitu 7,26.

Apabila dilihat berdasarkan penguasaan tiap indikator kemampuan pemecahan masalah matematis, siswa yang mempunyai gaya kognitif FI juga lebih unggul daripada siswa FD. Ringkasan data penguasaan tiap indikator kemampuan pemecahan masalah matematis siswa FD dan FI disajikan dalam Tabel 7. Hasil penelitian ini didukung oleh penelitian sebelumnya (Amazue, 2006; Daniels \& Moore, 2000; Davis \& Cochran, 1990; Tinajero \& Paramo, 1997 dalam Mefoh, Nwoke, Chukwuorji \& Chijioke, 2017) yang mengamati bahwa siswa FI biasanya menunjukkan tingkat pencapaian yang lebih tinggi pada banyak operasi kognitif daripada siswa FD. 
Tabel 7. Penguasaan Indikator KPMM Berdasarkan Gaya Kognitif

\begin{tabular}{|c|c|c|c|}
\hline \multirow{2}{*}{ No. } & \multirow{2}{*}{ Indikator } & \multicolumn{2}{|c|}{ Persentase $(\%)$} \\
\hline & & FD & FI \\
\hline 1. & $\begin{array}{l}\text { Menyelesaikan masalah matematis tertutup dengan konteks di } \\
\text { dalam matematika. }\end{array}$ & 51,47 & 80,00 \\
\hline 2. & $\begin{array}{l}\text { Menyelesaikan masalah matematis tertutup dengan konteks di } \\
\text { luar matematika. }\end{array}$ & 47,79 & 70,83 \\
\hline 3. & $\begin{array}{l}\text { Menyelesaikan masalah matematis terbuka dengan konteks di } \\
\text { dalam matematika. }\end{array}$ & 33,82 & 59,17 \\
\hline 4. & $\begin{array}{l}\text { Menyelesaikan masalah matematis terbuka dengan konteks di } \\
\text { luar matematika. }\end{array}$ & 48,53 & 61,67 \\
\hline
\end{tabular}

Selain itu, dari hasil uji regresi diperoleh persamaan regresi linear $\hat{Y}=3,703+0,512 X$. Model regresi tersebut menunjukkan bahwa setiap kenaikan satu skor gaya kognitif akan diikuti oleh peningkatan skor kemampuan pemecahan masalah matematika sebesar 0,512 unit pada konstanta 3,703. Temuan ini dapat dipahami dari sudut pandang teori gaya kognitif yang mengungkapkan bahwa kepribadian siswa FI ditandai oleh pendekatan penemuan aktif untuk belajar, orientasi individu, minat analitis, dan penekanan tugas. Semua atribut ini memiliki kontribusi yang cukup besar dalam meningkatkan kinerja tugas. Sebaliknya, kepribadian siswa FD biasanya memilih halhal yang mudah dan cenderung pasif dalam konteks pembelajaran sehingga cenderung memiliki kinerja yang rendah (Wapner dalam Mefoh, Nwoke, Chukwuorji \& Chijioke, 2017). Hal tersebut sejalan dengan penelitian Anthycamurty \& Saputro (2018) yang menemukan bahwa siswa FD tidak dapat memenuhi semua indikator dalam proses pemecahan masalah yang meliputi memahami masalah, membuat rencana, melaksanakan rencana, dan meninjau kembali hasil penyelesaian, sementara siswa FI dapat memenuhi semua indikator proses penyelesaian masalah meskipun kadang-kadang masih terdapat kesalahan.

Kelemahan penelitian ini adalah peneliti belum melakukan penelitian eksperimen dengan menerapkan sebuah model pembelajaran pada dua kelompok sampel sehingga dapat diketahui apakah terdapat perbedaan yang signifikan kemampuan pemecahan masalah matematis antara siswa FI dan siswa FD. Untuk penelitian selanjutnya, perlu dikaji perbedaan pencapaian kemampuan pemecahan masalah matematis siswa ditinjau dari gaya kognitif dengan menerapkan model pembelajaran tertentu.

\section{KESIMPULAN}

Berdasarkan hasil penelitian yang telah dilaksanakan di SMP N 2 Rembang, diperoleh simpulan sebagai berikut. Terdapat hubungan positif yang kuat antara gaya kognitif dan kemampuan pemecahan masalah matematis siswa. Siswa yang mempunyai gaya kognitif FI mempunyai kemampuan pemecahan masalah matematis lebih baik dibandingkan dengan siswa yang mempunyai gaya kognitif FD. Selain itu, gaya kognitif berpengaruh positif terhadap kemampuan pemecahan masalah matematis siswa sebesar $40,5 \%$.

\section{DAFTAR RUJUKAN}

Anthycamurty, R. C., \& Saputro, D. R. S. (2018). Analysis of Problem Solving in Terms of Cognitive Style. Journal of Physics: Conference Series, 983(1), 012146.

Arnup, J. L., Murrihy, C., Roodenburg, J., \& McLean, L. A. (2013). Cognitive Style and Gender Differences in Children's Mathematics Achievement. Educational Studies. 39(3), 355-368.

Charles, R. (1994). How to Evaluate Progress in Problem Solving. Virginia: National Council of Teachers of Mathematics. 
Elita, G. S., Habibi, M., Putra, A., \& Ulandari, N. (2019). Pengaruh Pembelajaran Problem Based Learning dengan Pendekatan Metakognisi terhadap Kemampuan Pemecahan Masalah Matematis. Mosharafa: Jurnal Pendidikan Matematika, 8(3), 447-458.

Hendriana, H. \& Soemarmo, U. (2014). Penilaian Pembelajaran Matematika. Bandung: PT. Refika Aditama.

Hendriana, H., Johanto, T., \& Sumarmo, U. (2018). The Role of Problem-Based Learning to Improve Students' Mathematical Problem-Solving Ability and Self Confidence. Journal on Mathematics Education, 9(2), 291-300.

Indrawan, P. \& Poppy, Y. (2016). Metodologi Penelitian Kuantitatif, Kualitatif, dan Campuran untuk Manajemen, Pembangunana, dan Pendidikan. Bandung: PT. Refika Aditama.

Jena, P. C. (2014). Cognitive Styles and Problem Solving Ability of Under Graduate Students. International Journal of Education and Psychological Research, 3(2), 71-16.

Khatib, M., \& Hosseinpur, R. M. (2011). On the Validity of the Group Embedded Figure Test (GEFT). Journal of Language Teaching \& Research, 2(3), 640-648.

Lu, H. \& Lin, P. (2018). A Study on the Effect of Cognitive Style in the Field of STEM on Collaborative Learning Outcome. International Journal of Information and Education Technology, 8(3), 194-198.

Mall-Amiri, B., \& Arabgol, M. (2015). The Comparative Impact of Visual Aids and Contextualization on Field-dependent and Field-independent EFL Learners' Vocabulary Retention. Journal of Language Teaching and Research, 6(1), 163-171.

Mefoh, P. C., \& Ezeh, V. C. (2016). Effect of Field-Dependent versus Field-Independent Cognitive Styles on Prospective And Retrospective Memory Slips. South African Journal of Psychology, 46(4), 542-552.

Mefoh, P. C., Nwoke, M. B., Chukwuorji, J. C., \& Chijioke, A. O. (2017). Effect of Cognitive Style and Gender on Adolescents' Problem Solving Ability. Thinking Skills and Creativity, 25, 47-52.

Onyekuru, B. U. (2015). Field Dependence-Field Independence Cognitive Style, Gender, Career Choice and Academic Achievement of Secondary School Students in Emohua Local Government Area of Rivers State. Journal of Education and Practice, 6(10), 76-85.

Saracho, O. N. (1997). Cognitive Styles in Early Chilhood Education. London: Bergin and Garvey.

Shodikin, A. (2016). Peningkatan Kemampuan Pemecahan Masalah Siswa Melalui Strategi AbduktifDeduktif pada Pembelajaran Matematika. Kreano, Jurnal Matematika Kreatif-Inovatif, 6(2), 101-110.

Sugiyono. 2010. Statistika untuk Penelitian. Bandung: Alfabeta.

Susanto, B. (2015). Peningkatan Kemampuan Siswa Dalam Memecahkan Masalah Matematika Bentuk Cerita Melalui Pendekatan Scientific Terintegrasi Pada Problem Based Learning (PBL) (PTK pada Siswa Kelas VIIE Semester Genap di SMP Negeri 2 Sawit Tahun Ajaran 2014/2015). Disertasi. Universitas Muhammadiyah Surakarta. 